\title{
An Analysis over Physical and Physiological Parameters of Elementary School Children Taking Part in A Sport Climbing Exercise
}

\author{
Emrah Aykora \\ Physical Education and Sports School, Bitlis, Turkey
}

Copyright $(2019$ by authors, all rights reserved. Authors agree that this article remains permanently open access under the terms of the Creative Commons Attribution License 4.0 International License

\begin{abstract}
This study is intended to analyze any improvement in flexibility, balance, strength (hand, grip, arm, torso, leg) and physiological (body weight, body mass index, body fat percentage) parameters for elementary school children with no background of sport climbing in a sport climbing training they attend. The physical and physiological parameters of the subjects were measured at the outset of the study and at the end of month two. Height $(\mathrm{H})$, body weight $(\mathrm{W})$, body mass index (BMI), body fat percentage (BFP), Flamingo Balance Test (FBT) for balance, Sit and Reach Test (SRT) for flexibility, Standing Broad Jump (SBJ) for explosive leg power, Sit-Ups Test (SUT) to be performed in 30 seconds for abdominal strength, Bent Arm Hang (BAH) test for endurance, hand grip strength (HGS) test for grip, and $10 \times 5$ meter shuttle run (SR) tests for sprint speed were conducted as a part of preliminary and posttests. The subjects took part in a 90-minute sport climbing exercise on a daily basis. The results of the preliminary and posttests pointed to a significant difference of $\mathrm{p}<.001$ in body weight, body mass index, balance, flexibility, torso strength, arm strength, grip strength and sprint speed, and of $\mathrm{p}<.005$ in body fat percentage. There was no significant difference between preliminary and post test results of the students who did not take part in any sport climbing exercise. In conclusion, physical and physiological parameters of students who take up sport climbing as early as in an elementary school do improve.
\end{abstract}

Keywords Sport Climbing, Elementary, Physical Parameters, Physiological Parameters, Physical Activity

\section{Introduction}

Climbing is a sport discipline with both physical and physiological requirements [4]. That is why climbers are supposed to boast a good physical performance and be psychologically set for climbing. Rock climbing has gained popularity over the past 15 to 20 years as a both recreational physical activity and a competitive sport [15]. Rock climbing has become a competitive international sport with an annual international World Cup competition circuit beginning in 1989 on artificial climbing walls [21]. Sport climbing is a mathematical and physical problem-solving skill that has no match in any other sport discipline. Climbing offers a vertical dimension to the combination of body and mind [17]. Certain motor skills loom large in many sport disciplines to succeed. Unlike any other sports, the performance of sport climbing relies on physical, technical and mental elements to an almost equal extent. While there are a myriad of physical factors that play a role in climbing performance, the most significant ones are strength, continuity in strength, flexibility, coordination, balance and anthropometric qualities [5]. It was a meeting organized at the Department of Sport Activities of General Directorate of Sports in Ankara on March 29, 2018 when sport climbing was introduced as a school-based sport by means of initiatives taken by the Turkish Mountaineering Federation [18]. The growing global interest in sport climbing has resulted in various studies carried out by researchers with focus on this discipline. The studies have looked into both anthropometric and physiological performance of adult athletes and injuries and means of protection. The number of studies that analyze physiological qualities of sport climbers is exponentially rising. This study seeks to identify physiological and strength-based parameters of children who begin to take up sport climbing.

\section{Methods}

The study analyzes the impact of sport climbing training on motor skills of elementary school students. 
The study included elementary school children (between the age of 8 and 10). Ahead of the study, the Physical Education Teachers working for the elementary schools across the central district of Bitlis were contacted to engage in a thorough exchange of information. The study included students with no background of being guided for any sport or doing any sports in an active fashion. The parents of the students were communicated with a "Parent Consent Form" to grant their permission to allow their children to be part of the study. All the measurements were conducted at the Physiology Laboratory of Physical Education and Sport Vocational School, Bitlis Eren University. Sport climbing training sessions were held at the Climbing Gym of the Physical Education and Sport Vocational School. The target population of the study comprised students who have not previously done any regular exercise and delivered a signed "Parent Consent Form". It was declared that those failing to deliver a signed Parent Consent Form, those suffering from any extremity injury over the past 3 months, those with hearing or visual impairments, circulatory or respiratory disorders, those doing exercise on a regular basis, and those failing to show up for the study for 2 consecutive times or 3 times in total would be excluded from the study. In addition, the participants were informed of the fact that they could leave the study at will. Following the selection of the participants who managed to meet the requirements, 28 women and 38 men $(n=64)$ were divided into a control group (CG, $n=32$ ) and an exercise group (EG, $n=32$ ) by means of simple random sampling. The initial measurements were recorded between 2nd of April and 6th of April, 2018, and the mean age turned out to be 9.8 and the mean height $138.8 \mathrm{~cm}$. and the mean weight 34.23 $\mathrm{kg}$ at the time. The participants were made to do a 15-minute warm-up exercise ahead of any measurement. The training program run by the researcher was kicked off on 9th of April, 2018. One training session comprised warm-ups (10 min.), climbing training (70 min.) and cooling down (10 min.). The training sessions took 4 days a week for 8 weeks in total. The final measurements were conducted after a 10-minute dynamic warm-up on the day after the final session of the training program.

Measurements; Height ( $\mathrm{H}$ ) for body composition, body weight (W), body mass index (BMI), body fat percentage (BFP), Flamingo Balance Test (FBT) for balance, Sit and Reach Test (SRT) for flexibility, Standing Broad Jump (SBJ) for explosive leg power, Sit-Ups Test (SUT) to be performed in 30 seconds for abdominal strength, Bent Arm Hang (BAH) test for endurance, hand grip strength (HGS) test for grip, and $10 \times 5$ meter shuttle run (SR) tests for sprint speed were conducted as a part of preliminary and posttests. The body composition was measured by InBody 270 Body Composition Analyzer that performs measurements in line with the same standards for age and gender. The device has been previously opted for in many scientific studies $[20,10,8,14]$. The flexibility was measured by a standardized sit and reach table (Lafayette Instrument Company, Lafayette, IN) as a common method to analyze hamstring and torso flexion. The participants warm up for 5 minutes and then sit down, with their feet flat and leaning onto a panel, and tilt their torso forward without bending knees, and try to push the slipping bar by their hands to the maximum extent. They wait for a couple of seconds before stretching forward and backward at the remotest point. The higher value is recorded out of two attempts [12]. Takei's TKK 5401 model (Grip-D, Takei Scientific Instruments Co. Ltd., Tokyo, Japan) hand grip dynamometer was put to use to assess the strength of hand grip. The instrument views the strength of left and right forearm flexors in kgf. A five-minute warm-up is then followed by the adjustment of the dynamometer according to the participant's hand. The measurement is conducted once the participant stands up, with his/her arm making a $30^{\circ}$ angle to the body without bending his/her arm measured and contacting the body. This is repeated for the right and left hand twice and the peak value is recorded. A 30 -second break is taken between sets.

In order to explore the static balance of the participants, The Flamingo Balance Test was utilized with a view to exploring the static balance in participants. The reliability coefficient of static balance was 0.87 [6]. The test revealed that the study group stood on a stabilometry platform of $50 \mathrm{~cm}$ in length, $4 \mathrm{~cm}$. in height and $3 \mathrm{~cm}$. in width with the dominant/preferred foot and tried to achieve their balance. The other free leg was bent backward from knee, pulled up to hips and gripped with the hand on the same side and time started when the participants achieved his/her balance on one foot and tried to keep his/her balance for one minute. When the participant lost his/her balance (giving up gripping the foot, falling off the platform, touching any part of the body, etc.), time was stopped. When the participant regained his/her balance on the platform, time was resumed. The test lasted for one minute. When time was up, the number of balance lost was counted, and the number was noted down as the balance score of participants at the end of the test.

\section{Data Analyses}

For processing of data, collected data were processed with SPSS 21.0 software. The Mann-Whitney U test (MWU) and the Wilcoxon Signed Ranks test were used for data analysis, frequency analysis and descriptive statistics. 


\section{Results}

Table 1. Comparison of Preliminary Test Results by Groups

\begin{tabular}{cccccccccccc}
\hline & W1 & BMI1 & BFP1 & FBT1 & SRT1 & SBJ1 & SUT1 & BAH1 & HGSleft1 & HGSright1 & SR1 \\
\hline MWU & 380.000 & 465.000 & 449.500 & 416.000 & 444.000 & 368.000 & 476.000 & 426.000 & 478.000 & 472.500 & 437.500 \\
\hline $\mathbf{Z}$ & $-1,773$ &,- 632 &,- 840 & $-1,298$ &,- 914 & $-1,935$ &,- 486 & $-1,155$ &,- 459 &,- 533 & $-1,011$ \\
\hline $\boldsymbol{p}$ &, 076 &, 527 &, 401 &, 194 &, 361 &, 053 &, 627 &, 248 &, 646 &, 594 &, 312 \\
\hline
\end{tabular}

Performed in an effort compare the initial measurements of all variables for both groups, Mann-Whitney U test offered no significant difference.

Table 2. Comparison of Post Test Results by Groups

\begin{tabular}{cccccccccccc}
\hline & W2 & BMI2 & BFP2 & FBT2 & SRT2 & SBJ2 & SUT2 & BAH2 & HGSleft2 & HGSright2 & SR2 \\
\hline MWU & 443.500 & 442.000 & 451.500 & 233.500 & 278.000 & 498.000 & 335.000 & 311.000 & 361.500 & 358.000 & 176.500 \\
\hline $\mathbf{Z}$ &,- 921 &,- 940 &,- 813 & $-3,769$ & $-3,144$ &,- 188 & $-2,390$ & $-2,699$ & $-2,026$ & $-2,075$ & $-4,547$ \\
\hline $\boldsymbol{p}$ &, 357 &, 347 &, 416 & $\mathbf{, 0 0 0}$ & $\mathbf{, 0 0 2}$ &, 851 & $\mathbf{, 0 1 7}$ & $\mathbf{, 0 0 7}$ & $\mathbf{, 0 4 3}$ & $\mathbf{, 0 3 8}$ & $\mathbf{, 0 0 0}$ \\
\hline
\end{tabular}

Performed in an effort to compare the final measurements of all variables for both groups, Mann-Whitney U test pointed to significant differences in Flamingo Balance Test, Sit and Reach Test, Sit-Ups Test, Bent Arm Hang Test, Hand grip Strength Test- left, Hand grip Strength Test- right and Shuttle Run test.

Table 3. Comparison of Pre and Post Test Results within Groups

\begin{tabular}{|c|c|c|c|c|}
\hline Parameters & Groups & Measurements & $\mathbf{Z}$ & $p$ \\
\hline \multirow{2}{*}{ W } & Exercise & Pre-Post & $-4,861$ & ,000 \\
\hline & Control & Pre-Post & $-1,342$ & 180 \\
\hline \multirow{2}{*}{ BMI } & Exercise & Pre-Post & $-4,918$ & ,000 \\
\hline & Control & Pre-Post &,- 729 & ,466 \\
\hline \multirow{2}{*}{ BFP } & Exercise & Pre-Post & $-2,677$ & ,007 \\
\hline & Control & Pre-Post & $-1,414$ & 157 \\
\hline \multirow{2}{*}{ FBT } & Exercise & Pre-Post & $-5,051$ & ,000 \\
\hline & Control & Pre-Post & $-1,414$ & ,157 \\
\hline \multirow{2}{*}{ SRT } & Exercise & Pre-Post & $-5,107$ & ,000 \\
\hline & Control & Pre-Post & $-1,000$ & ,317 \\
\hline \multirow{2}{*}{ SBJ } & Exercise & Pre-Post & $-5,112$ & ,000 \\
\hline & Control & Pre-Post & $-1,633$ & ,102 \\
\hline \multirow{2}{*}{ SUT } & Exercise & Pre-Post & $-5,086$ & ,000 \\
\hline & Control & Pre-Post & $-1,897$ & ,058 \\
\hline \multirow{2}{*}{ BAH } & Exercise & Pre-Post & $-5,443$ & ,000 \\
\hline & Control & Pre-Post &,- 184 & ,854 \\
\hline \multirow{2}{*}{ HGS left } & Exercise & Pre-Post & $-5,140$ & ,000 \\
\hline & Control & Pre-Post & $-1,057$ & 290 \\
\hline \multirow{2}{*}{ HGS right } & Exercise & Pre-Post & $-4,481$ & ,000 \\
\hline & Control & Pre-Post & $-1,857$ & ,063 \\
\hline \multirow{2}{*}{ SR } & Exercise & Pre-Post & $-5,101$ & ,000 \\
\hline & Control & Pre-Post & $-1,414$ & 157 \\
\hline
\end{tabular}

Performed in an effort to compare the final measurements of all variables within groups in terms of preliminary and post tests, Wilcoxon Signed Ranks test pointed to significant differences in W, BMI, BFP, FBT, SRT, SBJ, SUT, BAH, HGS and SR. 


\section{Discussion}

The study pointed to a significant difference in the exercise group in terms of body weight, body mass index, body fat percentage, balance, flexibility, torso strength, arm strength, grip strength and sprint speed. Watts et al. [21] report that elite climbers are shorter in height, with less body weight and a significantly lower body fat percentage. Other researchers report similar outcomes. A significant increase was recorded for balance results. As a part of a study conducted back in 2001, Fjørtoft [1] had children play various games in a natural setting and found out major differences in their balance and coordination skills. The fact that there was a significant increase in flexibility of the participants in the exercise group is compatible with the literature, as well. There are studies in literature that argue regular exercise has a positive impact on enhanced flexibility. Nelson et al. [11], reported a boost in flexibility for stretching exercises. Tekin et al. [19], reported similar results in an exercise program run for three months with female college students suffering from obesity. The results of the tests performed for a long-jump with a pause pointed to a significant difference for the exercise group. Karagöz reported [7], significant differences in sprint and long-jump with a pause for the experimental group as a part of a program. These data are totally compatible with our study. A significant improvement was recorded for arm strength. Ranson et al. [13], reported significant differences in 20 meter-long sit-up sprints, long-jumps with a pause and grip strength as a part of their study. The participants significantly improved their grip strength. While most researchers came up with similar results, the results of some researchers vary even if only to a small extent. This can be caused by discrepancy in measurement instruments and methodologies adopted for the analysis of grip strength [2, 16]. Muehlbauer et al. [9] reported a significant improvement in grip strength as a part of their study based on sport climbing that involved sedentary young men and women.

\section{Conclusions}

In conclusion, the study sought to analyze the physiological and strength parameters for children who begin to take up sport climbing. As proven by scientific findings of this study, sport climbing offers a positive impact on physical and physiological development of people. The results of this study are expected to contribute to the studies previously conducted with focus on sport climbing. In the same vein, this will offer an opportunity for the discipline of sport climbing to be acknowledged in multiple aspects. This study can be further improved by working on various training modes and age groups.

\section{Acknowledgements}

Upon the final measurements, the children, who were a part of the exercise group as a part of the study, went on to compete in the Turkish Interscholastic Sport Climbing Contest organized in the city of Samsun on June 4 to 7 , 2018. Two students ranked 4th and one student ranked 3rd in the competition attended by 405 athletes from all over Turkey.

\section{REFERENCES}

[1] W. Fjørtoft, I. (2001). The Natural Environment as a Playground for Children: The Impact of Outdoor Play Activities in Pre-Primary School Children, Early Childhood Education Journal, Vol. 29, No. 2

[2] Grant, S., Hynes, V., Whittaker, A., Aitchison, T. (1996).Anthropometric, Strength and Flexibility Charecteristic of Elitand Recreational Climbers. J. Sports Sci., 14 (4), 301-304.

[3] Halder, K., Chatterjee, A., Pal, R., Tomer, O.S., Saha, M. (2015). Age related differences of selected Hatha yoga practices on anthropometric characteristics, muscular strength and flexibility of healthy individuals. International Journal of Yoga, 8(1), 37-46.

[4] Hodgson, C.I., Draper, N., McMorris, T., Jones, G., Fryer, S., Coleman, I. (2009). Perceived Anxiety and Plasma Cortisol Concentrations Following Rock Climbing with Differing Safety Rope Protocols, British Journal of Sports Medicine. 43 (7): 531-535.

[5] Hörst, E.J., (2008). Training for Climbing: The Definitive Guide To Improving Your Performance, Falcon Guides, Guilford, CT, United States.

[6] Johnson, R.E., Kirkendall,D.R., Gruber, J.J. (1987). Measurement and evaluation for PE. USA: Human Kinetics Publishers.

[7] Karagöz, H.(2009). Sporun İlköğretimde Okuyan Sekiz Yaş Grubu Çocuklarının Temel Motor Özellikleri Üzerine Etkisinin Araştırılması. Yüksek Lisans Tezi, Kütahya Dumlupınar Üniversitesi, Sağlık Bilimleri Enstitüsü, Beden Eğitimi ve Spor Anabilim Dalı.

[8] Kim, S., Yu, J. (2015). Changes of gait parameters and lower limb dynamics in recreational runners with achilles tendinopathy. Journal of Sports Science \& Medicine, 14(2), 284.

[9] Muehlbauer, T., Stuerchler, M., Granacher, U. (2012). Effects of Climbing on Core Strength and Mobility in Adults, Int J Sports Med, 33, 445-451

[10] Mulasi, U., Kuchnia, A.J., Cole, A.J., Earthman, C.P. (2015). Bioimpedance at the bedside current applications, limitations, and opportunities. Nutrition in Clinical Practice, 30(2), 180-193. 
[11] Nelson, A.G., Kokkonen, J., Arnall, D.A. (2005). Acute muscle stretching inhibits muscle strength endurance performance. Journal of Strength and Conditioning Research, 19 (2), 338-343.

[12] Otman, A.S., Demirel, H., Sade, A. (2003). Tedavi hareketlerinde temel değerlendirme prensipleri. Hacettepe Üniversitesi Fizik Tedavi ve Rehabilitasyon Yüksekokulu Yayınları, 3, 44-49.

[13] Ranson, R., Stratton, G., Taylor, S.R. (2015). Digit ratio (2D:4D) and physical fitness (Eurofit test battery) in school children, Early Human Development, 91 (5), 327-331.

[14] Seki, Y., Kakizaki, S., Horiguchi, N., Hashizume, H., Tojima, H., Yamazaki, Y. Kasama, K. (2016). Prevalence of nonalcoholic steatohepatitis in Japanese patients with morbid obesity undergoing bariatric surgery. Journal of Gastroenterology, 51(3), 281-289.

[15] Shee, A.W. (2004).Physiology of sport rock climbing, British Journal of Sports Medicine, 38, 355-359

[16] Su, C.Y., Lin, J.H., Chien, T.H., Cheng, K.F., Sung, Y.T. (1994). Grip Strength in Different Positions of Elbow and Shoulder. Archives of Physical Medicine and Rehabilitation 75 (7), 812-815.

[17] Şeren, M.S. (2018). Daha Yükseğe, Daha Hızlı, Daha Zeki ve Daha Dayanıklı. Patika, Trabzon Tenis Dağcılık Kayak İhtisas Kulübü Dergisi, Sayı:3, s. 40.

[18] TMF, Turkish Mountaineering Federation, (2018). Https://www.tdf.gov.tr/spor-tirmanis-okul-sporlari-bunyesi ne-katildi/, Last Access on July 20, 2018.

[19] Tekin, A., Tekin, G., Altay, B., Çalışır, M., Bayrakdaroğlu, S. (2015). Düzenli aerobik egzersiz programının üniversiteli obez kız ögrencilerin fiziksel, motorik ve psiko-sosyal parametrelerine etkisi. Spor ve Performans Araştırmaları Dergisi, 6 (1), 19-29.

[20] Tekin, A., Tekin, G., Aykora, E., Çalışır, M., Duyan, M. (2018). Kor Stabilite Antrenmanının Kadın Çalışanların Vücut Kompozisyonu ve Kor Fonksiyona İlişkin Kuvvet ve Esneklik Parametrelerine Etkisi, İnönü Üniversitesi Beden Eğitimi ve Spor Bilimleri Dergisi, 5 (1), 41-46.

[21] Watts, B.P., Martin, D.T., Durtchi, S. (1993). Anthropometric Profils of Elit Male and Femele Competative Sport Rock Climbers. Journal of Sport Sciences, 4(3), 113-7. 